\title{
UMA ESTRELA DE MIL PONTAS
}

João Adolfo Hansen

\author{
"Espraiar-se selvagemente e no entanto \\ atrás de tudo pulsa uma geometria inflextvel" \\ (Clarice Lispector - A Hora da Estrela. 6 ed. \\ Rio de Janeiro, José Olympio, 1981, p. 99)
}

Há um dispositivo-matriz na literatura de Clarice Lispector que consiste na dissolução da unidade imaginária da personagem quando posta em contato com o limite da sua auto-representação, geralmente na forma do informe e da materialidade do orgânico, figurados segundo o imaginário de uma liberdade livre que falta na (des)ordem humana. O dispositivo é de rigor e faz doer, pois técnica de despersonalização da generalidade do "humano" na inumanidade construída como aquém ou além dele, bestialidade ou santidade. Como em Guimarães Rosa, encena uma utopia do corpo; como nele, corrói a forma sensata que medeia a representação, faz emergir o fundo como efeito simbólico de não-simbólico; diferentemente dele, é técnica ablativa, transpōe, extrai e subtrai, para que na insignificância do resíduo também se evidencie o primado da razão que o opera, não importa aqui o amável desdém dos narradores de Lispector por suas criaturas tontas de tanta matéria, saudosas todas da verdade impossível do real e incapazes, finalmente, do salto decisivo que as dissolveria no inferno da insipidez do mito.

Assim como no romantico o bom selvagem e a sua robinsonada não são meramente regressão a uma vida natural mítica, pois sua liberdade no mato também é um futuro, alegorizando o princípio da livre-concorréncia pelo qual cada um se auto-represente abstratamente autônomo no mundo administrado, também em Lispector a sedução das personagens pelo orgánico não é meramente romantica, psicologista, intimista e regressiva. Nela, a coisidade também alegoriza, e em registro duplo: a absoluta mudez e insignificancia do orgânico figuram a não-autonomia construída personagem e seu mundo e também significam, na iminência do vir a ser outro do contato, a recusa de um 
mundo não, necessariamente, do mundo que implica a relativização da racionalidade que o ordena como razão narrativa.

Exterioridade pura, em Lispector o orgânico é matéria profunda que realiza o real; metáfora, vir a ser outro na ordem do imaginário e da escrita, forma regressivamente um dos pólos de uma oposição que a personagem sente como ainda não totalmente domada: o núcleo temático da sua experiência é, invariavelmente, o de uma percepção sem objeto, traduzida como iminência de evento decisivo, liberdade. Por isso também são estúpidos os animais domésticos da Autora, vagamente sentimentais e edipianos, os entreguistas, que em algum ponto de suas vidas obscuras concederam ser capturados nas malhas ambiguas do gregarismo; mais rosna a selva, eis a leoa, mais se intensifica a liberdade alegórica que a prática cotidiana da personagem nega, vivida por ela como ausência de referência que lhe constitua uma unidade na selvageria. Nesta linha, também os textos de bruxaria de Lispector, como os de Onde Estivestes de Noite, datados de um tempo de medo, são o arremedo empobrecidamente kitsch e paródico dessa animalidade alegórica: mímica da exceção, figuram a liberdade frustrada que vive de pequenas rações diárias de marginalidade consentida como campo de um poder pessoal secreto. Ventriloquia de um desejo mudo, essas galinhas e ratos e baratas e búfalos e bruxas são ectoplasmas decepcionadamente utópicos, enfim. Mediuns de uma falta radical de voz, significam que o coração selvagem tem a sua razão: o Jardim é aqui e agora e a personagem deverá aprender, na via-crucis que a leva a si mesma na experiência do orgánico, que o Espírito não virá porque nunca veio. A regra é incontornável, ainda que em suas formas degradadas, pois também em Lispector a personagem é o animal simbólico, o não-animal radical.

Lispector é uma vontade poderosíssima, eis também a extrema monotonia de seus textos e certamente a qualidade dessa repetição que escande as ablaçōes do seu dispositivo: muitas vezes kitsch e lacrimejantes leia-se, por exemplo, $A$ via C'rucis do Corpo -, são textos abstratíssimos, a confinar com a música, pois neles se encena uma estrutura evanescente, que $\mathfrak{e}$ a da relação precária da personagem com as casas do imaginário e as figuras que institucionalmente a enchem nele como corpo. Textos abstratos, dramatizam a inscrição e as passagens de uma a outra, complementando-as com a razão delineada na indeterminação que vai durante, no movimento de umas a outras, como mímese de um conceito que foge. Gaguejando na fímbria que separa cultura/natureza e outras oposições homem/mulher, adulto/criança - e contradiçōes classe/classe -, a escrita as desinscreve do corpo de papel da personagem deslocando-lhes as categorias para fazer com que experimente outras sínteses imaginárias enquanto a leva a um termo aparente das transformaçōes, a decepção de ser outro e, mais, o outro. Regredindo para aquém de si na alegoria, 
(17): 107-122, 1989.

a personagem recupera-se aquém do aquém, na iminência do mito: de algum modo quebrada e vencida, aquém do seu desejo, mas humanizada no fracasso do cupio dissolvi. Este é o anti-organicismo de Lispector, diga-se assim, seu anti-romantismo eficaz, ainda no melodrama, em recusar o mito e significar o incontomável da regra.

Segue-se que o problema sempre enfrentado pelos seus narradores não $\hat{\epsilon}$, de modo algum, o de definir essencias, determinando o que seja o orgânico, mas 0 de determinar a perspectiva pela qual a alegoria orgânica é formulada. Movendo-se sempre segundo uma relação desigual com o que narra $e$ com sua auto-representação no ato, o narrador produz indeterminação com função operatória, que evidencia contrastivamente o arbítrio da razão narrativa em outras palavras, a solução do problema consiste na auto-aplicação do dispositivo. Linhas incorporais de fuga se traçam como vir a ser sempre evanescente de fala no texto, secretando o resíduo legível como silêncio da forma no qual alguma coisa nunca cessa de não se escrever, como diria psicanalista, corpo e suas fiç̧ōes relativizados. Aqui, pois, a auto-aplicação do dispositivo pelo narrador figura a inépcia, que vinca os textos da Autora fazendo-os gaguejar de estupidez como condiçāo mesma de sua verossimilhança, pois explicita-lhes a razão. É que em Lispector a racionalidade do narrador se determina como imaginário cuja particularidade se sabe diferencial, assim como a convenção das personagens, e não quer, assim como as personagens não podem esvaziar-se nela, encher-se de natureza. Em outros termos, a dificuldade maior que enfrenta é, com lucidez, um problema pressuposto na elocução: $o$ ato de representar o orgânico e suas variaçōes insignificantes em sua autonomia de não-autonomia racional pertence a um mundo em que sua referência já está dominada a priori. Como formular o insignificante alegórico sem excluí-lo, isto é, sem inclur-lo numa fórmula apenas regressiva e não-livre? Geralmente, a escolha é pelo discurso relativo, votado ao fracasso encenado no próprio desempenho, paralelo ao fracasso efetuado das personagens, e que marca a qualidade superior desta arte. $O$ narrador se narra dissolvendo-se, fosse ele um defunto indeterminando-se, para impedir que uma fala plena de natureza reproduza o padrão institucional dos materiais - discursos das transformaçōes de seu Autor. É justamente o dispositivo que implica a impossibilidade, aparente ou não, que Lispector sempre tem de manter a continuidade da ação, várias vezes assinalada pela crítica presa à doutrina clássica da sequéncia lisa e clara. Aqui é mais oportuno postular que a impossibilidade do texto contínuo e longo năo é de Lispector, mas da vontade encenada de seus narradores pela ação abstrata, além de ser, como se disse, impossibilidade evidenciada como recusa da naturalização das formas em que a Autora intervém quando as dramatiza em seus textos. Eleiçăo das idéias lúcidas apropriadas ao ato, não importa aqui o bom ou o mau gosto também 
convencionais das situaçōes dramáticas e caracterizações, trata-se de se deixar vir a ser tudo quanto é orgânico sem o organicismo do horror sem objeto de se pensar outro, galinha, rato, fruto adocicado que apodrece enfim, convenção aplicada de auto-dissolução. Como falar dessas coisas? Espelhamento apaco, o insignificante significa o grande outro do narrador e, certamente, do Autor real e seus leitores: a historicidade da razão que os refrata fracassados no texto como parcialidade da divisão prática, que é o que realmente importa.

Em A Hora da Estrela, escrito em contraponto com Um Sopro de Vida, também último, a personagem Macabea realiza hiperbolicamente o dispositivo: ela é besta. Com o termo, significa-se uma cegueira radical, e radical porque cega sobre si, que a faz plena de si sem si, sem carencia, sem falta e outros termos da privação. Sua fala coincide absurdamente com o que diz; não tem o que se chamaria "felicidade", pois não tem memória, a não ser a da atualidade da fome atávica limite do narrador, e assim não tem o que se entende por "projeto"; morre alegoricamente, aliás, quando o futuro aponta. Sua percepção de personagem não é formulada numa ordenação sucessiva, dando-se como temporalidade congelada na duração em que o percebido é corpo. Atual como um gato, não tem distanciamento, sendo atemporal; sem reflexão, é exterioridade e, assim, imediatamente profundeza. Vive algo impossível: é o imagionário menos o simbólico: um bruto troço de matéria que, na literatura brasileira comtemporânea, só tem similar nos adynata do Hermógenes, de Grande Sertão: Veredas. Na obra de Lispector, é a metáfora intensificada, - e finalmente realizada -, que agora se personaliza na impessoalidade soberba, do mundo vegetal do Jardim Botânico, dos animais da Arca e das inúmeras Evas tontas que esperam distraídas o nome que as desencante para os ritos do amor transitivo. Ela é impossível, posto que não inverossímil, e é da estirpe de Joana, de Perto do Coração Selvagem; de Virgínia, de O Lustre; de Lucrécia, de $A$ C'idade Sitiada; de Martim, da primeira parte de A Maçã no Escuro; de Loreley, de Uma Aprendizagem ou o Livro dos Prazeres; de G. H., de A Paixão Segundo G. H.; de Miss Algrave, de A Via C'rucis do Corpo. Diferença desı semelhança: Macabea é de outra classe, ela que é uma desclassificada, ao contrário das outras personagens "classe média" típicas de Lispector, e representada a viver como cotidiano o que para elas é a vertigem alegórica e, para a crítica, analítica existencial da angústia. Por isso também não pode ter recurso ao discurso teórico, metaforicamente filosófico ou científico, que, do mesmo modo como motiva o verossímil das personagens com seus confortos explicativos, poderia torná-la acessfvel para si mesma ao definir-lhe o nonsense da experiencia (como a filosofia, por exemplo, para Joana, Loreley, G. H.; ou a Ciencia, para o engenheiro Martim). É despossufda mesmo do bom senso comum das mães de famflia de Lispector, às voltas com fogões que estouram, filhos no colégio, 
HANSEN, Jớo Adolfo. Uma estrela de mil pontas. Lingun e Literatura, Săo Paulo,

(17): 107-122, 1989.

maridos, como a Ana de "Amor". Em sua liberdade alegórica, Macabea só encontra imagem na estupidez da galinha do cinto de Laços de Família e alguns ecos na marginalidade amoravelmente criminosa de "Mineirinho" ou no desamparo pungente de Mocinha, a velha de "Passeio a Petrópolis", de A Legião Estrangeira.

Macabea, contudo, não é santa, nem animal, nem sequer besta: é constituída como tal na relação desigual com a racionalidade do narrador. Em outros termos, a constituição dela como exterior a si e a tudo evidencia para o leitor que ela só é estúpida, animal ou santa pela relaçāo desigual com o que se pensa "livremente" como não-estúpido, não-animal, não-santo, e que as articula como positividade plena de si como primeiro termo das oposições Sul/Nordeste; literatura/analfabetismo; crítico/alienado; racional/irracional etc. É que, pelo aparato institucional que a produz e reproduz como exclusão includente, dominação, a estupidez referência de Macabea é ausência de forma, silêncio de indeterminaçāo; não se pode dizê-la, assim como não pode por si só enunciar-se como tal. É que dizé-la já é estúpido em si, pois gesto mimético vazio a imitar absurdamente uma ausência de forma. Gesto que se torna paródico, porém não da estupidez que, pelo seu próprio pressuposto, não é forma a ser resposta, mas de seu mesmo movimento de gesto, intencionalidade ou possibilidade como mímese. Paródico, assim, da determinação racional da sua possibilidade, é imediatamente cómico, irrisório, pretensiosamente solipsista: basta ousar começar. E o narrador de $A$ Hora da Estrela ousa, sabendo: por isso afirma também repetidas vezes querer os "fatos" que o eximiriam de narrar. Ora, falar da estupidez - e aqui a alegoria sempre conforma a classe da personagem refratando-se na estupidez da do narrador - implica fazê-lo na dimensão da sua possibilidade, não na da sua realidade efetiva, enfim. Fazê-lo é produzir um discurso como linguagem de fiç̧ão cujas inflexões ineptas dramatizam a ficção da linguagem em que a racionalidade do narrador se estilhaça em mil pontas ainda antes mesmo de iniciar.

Considerada a tradição da modernidade que naturalizou os modos imitativos baixos como verossímil privilegiado a vampirizar os detritos do Grande Costume, a encenação é banal: lê-se A Hora da Estrela com a familiaridade suposta de mil e uma experimentações afins, exercitadas com maior ou menor eficiéncia como alegoria da promessa de felicidade utópica, como crise e ranger de dentes, como desconstrução e dever de casa de metalinguagem dos heróis da negatividade positividada enfim, como tradição do novo hoje clássica no museu de tudo do conformismo e ópera bufa. Em A Hora da Estrela, contudo, a contradiçāo é irredutível: como extensăo narrativa da divisão da banalidade prática, a dramatização contínua da "geometria inflexível" é complementar da estupidez da personagem e narrador, de tal modo que a ficçăo da unicidade do 
(17): 107-122, 1989.

texto como obra implica sua impossibilidade mesma. Como o Machado de Memórias Póstumas ou no Rosa de Grande Sertão: Veredas, é obra não-obra, fraturada, e só funciona quando emperra.

Experimentação que lembra a técnica da exposição distanciadora no teatro épico, o texto dispōe-se como gestualidade de seu autor implícito, que a si mesmo se oferece como destinatário da sua impossibilidade prática de narrar, desdobrando-se na voz de um narrador narrado, Rodrigo S.M.; noutra articulação justapõem-se as indeterminações da personagem. Aparentemente autônoma em relação a significados da posição de classe imaginária do autor implícito e do narrador, Macabea é criatura deles. Sua autonomia relativa de não-autonomia é implicada por sua constituição alegórica, aliás, que a desdobra: generalidade de abstração e personagem individualizada. $O$ sentido figurado superpóe-se no final ao próprio e ao tempo entrevisto como projeto pela personagem, abstraindo-se o futuro em sua morte o que, pesos e medidas, é uma perda que é um ganho, parcial, em termos da contradiçăo que permanece irredutível.

Escrevendo escrever para não morrer, representado na partilha das Luzes, o narrador desde o início ratifica a inviabilidade do projeto do autor implícito: dar forma literária àquilo que se furta à representação literária como voz autônoma da não-autonomia, uma vez que o projeto é o de fazê-lo agir não pela mediação das luzes que esclarecem as letras do intelectual, mas em sua particularidade produzida na relação desigual como iletrada, estúpida, mediatamente autônoma:

"Ah que medo de começar e ainda nem sequer sei o nome da moça. Sem falar que a história me desespera por ser demais. O que me proponho contar parace fácil e à mão de todos. Mas a sua elaboração é muito difícil. Pois tenho que tornar nítido o que está apagado e mal vejo. Com mãos de dedos duros enlameados apalpar o invisível na própria lama" (A Hora da Estrela, p. 24).

Convidado a indeterminar-se nesse ponto teoricamente prévio dos andaimes da obra, o leitor pode supor escolhas narrativas abertas pelo procedimento de especularidade: ou um autor em busca da sua personagem ou uma personagem em busca do seu autor. A segunda é própriamente dramática; a primeira é épica, no sentido genérico de "fabulaçāo", e determinante para compreender a relação contraditória que une, isto e, separa Macabea, Rodrigo, autor, leitor. O contínuo desnudamento do processo como inépcia tem aqui justamente a função de evidenciar os limites da prática do narrador, evidenciando-lhe a convenção da competência letrada enquanto evidencia a incompetência da sua convenção. A estupidez alegórica não pode ser dita num discurso não-estúpido, coerente segundo regras da racionalidade dominante, que é a do narrador: seu discurso pode apenas metaforizar-lhe o pathos, gesticular de 
(17): 107-122, 1989.

impotência fingindo a inépcia real, fragmentar-se ou propor o estilo sublime, que nesta sociedade também sublime só pode ser o chavão, o melodrama, o sangue e a sacarina do kitsch. Por isso, o narrador toma-se melodramático, metaforizando a impossibilidade prática e, embora não seja mulher, como afirma, também lacrimeja muito, fica piegas. Obviamente, o melodrama não é feminino, sua convenção é que às vezes o é, e Rodrigo só pode ordenar-se no discurso como desordenação, perda do sentido, vertigem que evidencia no nāo-sentido efeluado da sua prática de narrador o sentido prático das incoerências de Macabea, nonsense que repõe especulativamente o nonsense da sua situação de narrador. Por isso, a violentíssima redução da humanidade de Macabea à insignificáncia animal aquém dela não significa, meramente, a assunção de uma perspectiva exterior, privilegiada e dominante sempre, pela qual sua inutilidade e ignorância produzidas pudessem ser tomadas como inutilidade e ignorância de fato e, assim constituídas da perspectiva dominante, continuassem dominadas ainda que o discurso sobre ela fosse empático, como costuma ser na indignação, na comoçāo etc. A operação de Lispector é sutil porque absolutamente crua, consistindo num procedimento de transposição alegórica que, ao desinvestir a personagem dá sua humanidade fixando-a como um emblema da estupidez das coisas, retém a formulação esvaziada daquilo que, apenas humana, ela efetivamente é: empregada no comércio, força de trabalho. A operação implica, portanto, a encenação da condição prática do intelectual brasileiro contemporâneo, que o texto inclui assimétrica e dissonantemente, e a dos materiais discursos de que dispõe para intervenção artística "crítica" A Hora da Estrela não soluciona a questão, é evidente, nem poderia fazê-lo, senão alegoricamente, quando o autor implícito faz o narrador tomar posição. A virtude do texlo, diga-se assim cristãmente, é que repropõe a questão prática como seu limite e o faz de modo radical, que também implica a recusa do "cristãmente" e de toda conciliação imaginária, proibindo toda esperança para a personagem, como recusa e negação. Neste sentido, a escrita desvia-se do que é institucional: falar sobre, isto é, falar por, como um qualquer doador de consciência faria. A recusa tem um preço e o primeiro, óbvio, é a dispersão da fala. Alegoricamente, pois, a questão da representação literária também se encena como homóloga à de outras práticas discursivas, como a filosofia ou a psicanálise quando propõem o "como falar a loucura" não da, ou sobre, ou a partir de, ou em torno de mas, impossivelmente, como dizê-la sem que o mesmo discurso seja simultaneamente louco, suposta sua racionalidade suposta como determinação. Rigor de Lispector, questão irrespondida pelo seu texto que só a responde quando a conforma ná metáfora do informe, num primeiro esforço sempre retomado e que fracassa, o discurso do narrador é um devir-Macabea, fazendo-se como técnica do negativo. Aqui, a metáfora religiosa comparece como figuração do sentido esvaziado e 

(17): 107-122, 1989.

vazio de seu gesto: "Por enquanto quero andar nu e em farrapos, quero experimentar pelo menos uma vez a falta de gosto que dizem ter a hóstia. Comer a hóstia será sentir o insosso do mundo e banhar-se de não "(p.25). Tema recorrente, aliás, que se lembre G.H. e sua barata. Lispector é materialista, contudo, e nāo se trata de "religiāo", que é o avesso metafórico cômodo da soberba despersonalização do seu dispositivo.

A inépcia do narrador, isto é, sua capacidade técnica de produzir inépcia como deslocamento, retardamento, tautologia, anti-clímax, humor, indeterminação etc. é determinada pela impossibilidade prática do autor implícito, já se disse, que não pode dar forma unitária à contradição. Por isso, enquanto escreve, Rodrigo esvazia a significação do que escreve e do ato, interpondo-se como obstáculo ao ato e ao significado; à medida que os esvazia, enche páginas que o efetuam como objeto em sua agonística encenada para o destinatário. Este está sempre na iminência de algo próprio do gênero cômico, farsa ou burla: escreve muito bem alguém que se diz incapaz de escrever. $O$ leitor, nem grave, nem frívolo, pode porventura perguntar pela funcionalidade do procedimento que o dramatiza na figura do destinatário assim e aqui na inépcia, propondo-lhe continuamente a experiéncia da fratura e do emperramento. Resposta plausível é dizer que implica instá-lo a uma participação na inépcia sem a inépcia - de imediato, explicita-se uma razão astuta a encenar a particularidade de sua prática explicitando-lhe os limites, o que implica a emergência do fundo referido, quando a forma se dissolve. Simultaneamente - e isto é mais oportuno implica também os limites da constituição de tal fundo que, dado a (des) ler como um expresso emotivo, psicologia da Clarice intimista, ou como um inefável inexpresso, coisa ou Deus da Clarice místico-heideggeriano-metafísica, é absolutamente superfície da letra, efeito simbólico de não-simbólico produzido numa prática datada como prática datada, Lispector calculista do rigor. A inépcia rebate-se, portanto, nas opções narrativas da Autora. Ünificar a divisão seria basicamente inverossímil, pois proporia o verdadeiro melodrama na falsa conciliação de um destino feliz da personagem e, ainda, de uma ingenuidade épica impossível do narrador. Por exemplo, fazendo Macabea casar-se com Hans, o gringo montado na micro-alegoria do Mercedes Benz ou, ainda, fazendo-a acalentar esperanças "quanto ao futuro" Por ricochete, seria revalidar a tristeza da Rua do Acre, o arrivismo de Olímpico, a satisfação de Glória, o sublime do patrão que le Humilhados e Ofendidos, a manifestação machadianamente transposta de Madama Carlota, representados a viver a ficção da normalidade institucional em relação à qual Macabea é exótica e anormal.

O texto abre-se assim para outra fratura encenada: o efeito deixa-se apreender pelo destinatário como representação unificada de uma vida de escritor em crise que o indetermina em inépcia; e o procedimento encena-se a 
si mesmo como prática que, letradíssima, confina com o nāo-letrado, seu pólo contraditório. Assim, o autor implícito, evidentemente disfarçado no biografema musical do início do livro e, em vários sentidos, efetivamente final da "Dedicatória do Autor (na verdade Clarice Lispector)", objetiva o desespero nesse Rodrigo S. M. de má-consciência, cresce-lhe uma barba, pendura-lhe umas olheiras, priva-o de sexo, monta-o como persona apta para rapidamente teorizar a inépcia da marginalidade equivocadamente marginal do intelectual brasileiro da especialidade escritor, representada como "de exceção" que, muito distraidamente, assim como quem vive, escreve um livro assim como se fabrica todo presunto, Clarice Lispector "socióloga" - por pouco tempo, felizmente:

"Sim, não tenho classe social, marginalizado que sou. A classe alta me tem como um monstro esquisito, a média com desconfiança de que eu possa desiquilibrá-la, a classe baixa nunca vem a mim" (p.24).

E ainda:

"(Se o leitor possui alguma riqueza e vida bem acomodada, sairá de si para ver como é às vezes o outro. Se é pobre, não estará me lendo porque ler-me é supérfluo para quem tem uma leve fome permanente. Faço aqui o papel de vossa válvula de escape e da vida massacrante da média burguesia"(p.38).

Correlato da inépcia do narrador, o inacabamento do livro impõe-se aqui como efeito de defeito apto para figurar a inadequaçāo prática. Em outros termos, o romance ultrapassa o efeito mimético da unificaçào do narrador e sua personagem na unicidade da obra, dramatizando, pelas inépcias cruzadas e simultâneas, a divisão existente entre pelo menos, duas formações imaginárias, também sendo efetuado por ela, que é determinada socialmente e determinante da prática escriturária. A inépcia representadamente real do autor implícito, emissário do Autor real que coloca títulos que denegam sua impotência - "Ela que se arranje", "A culpa é minha", "Eu não posso fazer nada", "Saída discreta pela porta dos fundos" - implica a inépcia do narrador narrado, enfim, apta para figurar a inépcia de Macabea, até certo ponto, como disfunção no efeito da recepção predeterminada pelas regras de unificação imaginária da leitura. Sua fala tateante é homóloga à mudez da insignificância representada da personagem, e nisto eles se tocam enquanto se separam como parcialidades da divisão.

$O$ dispositivo funciona por transposição e estrutura, para citar um inepto magnífico e sua pequena razão viril. Com o termo estrutura, significa-se aqui, muito simplesmente, o cálculo exato da correlação dos elementos e encaixes de inépcia, a ponto de produzir o efeito geral de inacabamento referido, de texto mal conseguido e de mau gosto ("História Lacrimogênica de Cordel"), segundo padrões da recepção que prescrevem o decoro do gosto. Por exemplo, pela dramatização sistemática de chavões, 
(17): 107-122, 1989.

pedaços petrificados de falas já anônimas, principalmente nas situaçōes de diálogo entre Macabea e Olímpico, Macabea e Glória, potenciando-se com Macabea e Madama Carlota esta, toda chavão, potenciada em alegoria mercantil. Reescrever a sério o que se dá mistificadamente como sério é evidentemente irônico, não como postulação de uma verdade do bom gosto exterior e superior, aliás também kitsch na afetação da sua Alta Costura mas como distanciamento inclusivo: afinal, o narrador afirma o tempo todo seu desejo de porcaria, no qual dramatiza também o destinatário na cena brasílica de sempre, pois se diz "...obrigado a usar as palavras que vos sustentam" (p.17). Trata-se, pois, de uma técnica da hipérbole a frio que, comuníssima em Lispector, na hiper-amplificação do kitsch opera a figuração alegórica ressaltando a humanidade de Macabea, único ser livre num mundo de mercadorias auto-suficientes em sua fiç̧ão cotidiana:"... capim é tão fácil e simples. Tinha pensamentos gratuitos e soltos porque embora à toa possuía muita liberdade interior" (p.86).

Por transposição significa-se uma técnica recorrente nos textos da Autora - de desfocamento sistemático ou atribuição equivocada de índices e eventos, numa espécie de trocadilho generalizado como humor por vezes negro, na medida adequada do rigor. Retoricamente, é uma técnica da catacrese, como nomeação imprópria ou "mau uso". Por exemplo, malvadamente fazer com que Macabea ouça seu futuro falado pela cartomante, o atropelamento, como profecia narrada para outra moça anônima, que sai da consulta com os olhos vermelhos; ou, humor negríssimo, calculadamente oportuno, fazer a personagem ser atropelada pelo Mercedes Benz amarelo quando sai esperando encontrar Hans, o gringo loiro. O desfocamento também se dá como microações incongruentes: Macabea olha-se no espelho do banheiro do escritório e não se vê; jura pela mãe morta dizendo a Olímpico que deseja que a mãe morra se estiver mentindo; lê "designar", corrige para "desiguinar"; fala de "élgebra", de "efimírides"; teme ser numa vida futura com Olímpico deputada, pois a palavia lembra coisa feia; e, hipérbole, justa medida para um tempo de sindicalismo de resultados, pede desculpas ao patrão por ser demitida. O efeito geral da técnica é o de uma miopia de bons olhos, para aqui reter da metáfora óptica de Gilda de Mello e Souza, em "O Vertiginoso Relance", não seu caráter normativo implícito (miopia $x$ visão normal), antes o do fingimento do fingimento como técnica de contrafação que se dá ao leitor como o olhar representadamente míope de alguém que enxerga nítido, distinto e cruel, e que usa faz de conta que usa - lentes deformantes para que na deformação o informe se forme e, na relação assimétrica, corrija-se o evidentíssimo que não se vê: a miopia da visão dita normal. A do leitor, por exemplo, convidado desde o início a teatralizar-se no efeito geral de inépcia sem ela. O que, mais uma vez, desfoca e borra, porque o 
(17): 107-122, 1989.

leitor, que muito normalmente é míope, tem agora de fingir que finge a miopia finginda para ver nítido o que sua visão normal não vê, pois institucionalmente informe, insignificante, invisível - e outros borramentos do prefixo negativo. Macabea, enfim: ela, que é uma maldita.

$\mathrm{Na}$ sua estupidez construída, Macabea é homóloga à racionalidade do narrador, já se disse; os sinais estão trocados, contudo, pois aqui a racionalidade se confessa irracional e inepta e a estupidez é a alegoria da racionalidade geral. É que, não sendo uma idiota substantiva no sentido em que a prática médica institucional racionaliza a normatividade dominante, Macabea é a metáfora idiota, porque nonsense e inepta, e por isso eficientíssima como feito literário que faz muito sentido e ultrapassa o "literário" da idiotia real, sua referência e condição: as relações normais cotidiana e a racionalidade que as ordena. Seu tema - suponha-se um - é portanto o da insipidez própria dos bichos da Autora, mas o de uma insipidez narrativa, efetuada não como substância do insípido, antes como alegoria do vazio na relação contraditória de discursos incompossíveis. Determinantes de Macabea, que no texto é a metáfora a ser enchida e simultaneamente esvaziada, é a grande fome atávica e seus buracos, limites da narrativa. Os índices são muito reiterados: o ovo; o café frio; a goiabada com queijo; o café pingado com muito açúcar, do qual Olímpico generosamente ameaça pagar $s \delta$ a metade; a experiência inebriante no açougue; $o$ chocolate, o bolo, o roubo do biscoito na casa de Glória; o pedido antigo à tia por óleo de fígado de bacalhau; a conversa estúpida com médico estúpido sobre macarronada; os bombons com licor de Madama Carlota; a impossibilidade sempre muito econômica de vomitar, saber só de experiência feito. Desses, principal é a reiterada afirmação de medo de sangue, que funciona como denegação da fome, Macabea que à noite fica alucinada pensando em coxa de vaca. Frente à fome, evidentemente, toda arte deixa de ser uma evidencia: na articulação do tema, o que faz o texto com o leitor é ler-lhe os critérios de legibilidade repropondo-os como irrisoriamente ineptos. No seu efeito espectral o ć́nico de detrito literário elaboradíssimo, as idéias-fome violentas do autor implícito terāo ainda, ele quer crer, alguma potencia afirmativa frente ao cinismo da fome de seu mundo. Ele reivindica " o direito ao grito" - e a Autora escreve, como um dos títulos, "Eu não posso fazer nada" - como articulação da desarticulaçāo do intelectual da especialidade escritor. A literatura nada pode, a não ser afirmar uma idéia forte como a da fome de Macabea, enfim, que determina, no caso, as idéias lúcidas, entre as quais a primeira é evitar toda idealização que torne a personagem ou o narrador simpáticos, em sua fome e em seu limite.

Em A Hora da Estrela há uma micro-figuraçāo desta fratura e da narrativa que se faz. Ela torna Macabea homóloga a qualquer escritor, do mais 
(17): 107-122, 1989.

apto ao mais inepto. É funcional que ela não fale, quase, e que ao mesmo tempo seja datilógrafa absolutamente incompetente. E divertidamente irónica a disjunçāo que, mais uma vez, encena a contradição: como datilógrafa, escreve no registro da escrita mediada pela tecnologia da eficiéncia produtiva o discurso do mundo comercial, de que é dispensável, facilmente reponível, improdutiva que é: "parafuso inútil numa sociedade técnica", diz dela o narrador em espelho. LE-se o que Macabea escreve de dentro da sua situação representada, mas também o que pode o Autor real do qual ela é a metáfora invertida, Clarice Macabea. Ponto por ponto, rebatem-se: inépcia, inutilidade, alienação. Como a regra que institucionaliza a incompetência é meramente provisória, contudo, sua encenação no texto também the explicita os limites: afinal, a sociedade técnica em que Macabea é parafuso dispensável não é uma sociedade indispensável. Resta ao Autor, como procedimento, o artifício de fazer do erro de datilografia uma opção programática, repropondo as classificações correntes e dissolvendo-lhes a Universalidade das formas. Para tanto, resta-lhe, enquanto racionalidade, o ser estúpido, experimentando linguagens que, no atrito e borramento contínuos, apontam para um resíduo cujo sentido se determina na leitura como real dividido. Por isso, muito fortemente, a estupidez de Macabea espanta e comove: o que pode significar que ela nos interroga com uma pergunta muda acerca da nossa posição e da racionalidade implicada nela como contradição violenta que Lispector deixa aberta sem resposta, pois no romance a solução só soluciona o romance.

Aqui se encontra a representação de uma falha, que faz Rodrigo S.M. soar deslocado e contrafeito na medida da sua naturalidade mesma, e que, na encenação da sua prática de escritor, redunda em defeito alegoricamente programático, isto é, em virtude. A falha é que Macabea não tem autonomia como personagem não-autônoma, sendo ora perspectivada pela situação do narrador, ora por sua posição. Sua não-autonomia, seu não-saber, sua exterioridade e sua estupidez, enfim, são teatralizados como momentos constitutivos do pensamento do narrador, pelo menos como parcialidade da relação desigual. A isto se deve, por exemplo, a técnica de construí-la como exposição de situações dramáticas pouco ou quase nada encadeadas como consecução, quase que por justaposição de quadros cuja descontinuidade só se unifica na voz dividida do narrador. É defeito, porque ainda sua liberdade narrativa de ser estúpida, de agir livremente como bicho não-autónomo, é-lhe expropriada. Assim, mesmo o declarado amor do narrador por ela é apenas amor declarado, desigual e exterior, não obstante se esforce para destruir a relaçăo quando, por exemplo, narra o presente contemporaneo da morte dela como se fosse um observador imparcial à merce do acaso dos eventos que ajnda pudesse salvá-la. No entanto, escreveu-se, a contradição fratura o texto de rabo a cabo: 
(17): $107-122,1989$.

deixar evidentes os cordéis da marionete era talvez a solução que se impunha a Lispector em termos da composiçăo do inacabamento. Em outros termos, lançar mão de inadequação em que o artificio ressalta operatoriamente, tendo em vista uma adequação superior da inépcia em termos de contradiçáo.

Aqui, pois, a posição de classe representada do narrador choca-se com os dados da sua situação: é que, pela sua posição, ainda que vagamente "crítica", ele efetivamente deseja a autonomia de Macabea, ou na forma de um "projeto" dela que, justamente por sua posição, ele tem que postular como autonomia de ação, ou mesmo na forma da sua não-autonomia como estupidez. Sua situação representada de intelectual, porém, é exterior, pois na relação desigual ele só pode falar sobre a personagem, com os meios que a situação lhe confere, não importa o quanto relativizados. A alternancia, na sua enunciação, de representações mais ou menos "críticas" da sua posição e de representações dominantes na sua situaçăo induz a que Macabea seja, assim, autônoma e não-autônoma. Dotada de vida própria enquanto designaçāo particularizante que, contudo, Ignora-se a si mesma, ela é, nesta autonomia, não-autônoma. Ao mesmo tempo, sem vida própria, enquanto significação generalizante ou construção intelectual do narrador, é alegórica de sua classe e de um desejo vagamente utópico da posição dele, de modo que, na sua não-autonomia alegórica, tem alguma autonomia, desigual e mesmo virtual. Nos dois registros simultâneos e complementares, Macabea apresenta uma autonomia relativa, pela mediação do narrador, praticamente obrigado à sua não-autonomia. Desta maneira, produz-se também um emperramento contínuo na sua constituição, que deslisa, na leitura, da sua não-autonomia ou alienaçăo como individualidade autônoma para sua autonomia como alegoria da não-autonomia social de sua classe: ela se dá "entre", nos deslocamentos, articulada por essa espécie de inverossimilhança em que o uno é duplo e o duplo, um. No caso, a inverossimilhança é o verossímil apropriado em termos da contradição, pois a questão narrativa, numa economla global, não se resolve apenas como problema do narrador, da personagem ou da unicidade do artefato literário. $O$ texto metaforiza a situaçáo e a posiçăo práticas do escritor real e do público leitor, numa técnica de desfocamento em que os dados da situaçáo sáo traduzidos por valores da posiçăo e vice-versa, sem unificaçăo possivel que, esta sim, seria falsa e inverossimil.

A estupidez de Macabea acaba sendo recebida como estupidez porque é, como a loucura, o năo-domínio da própria ficção. Contraposta, por sua vez, à racionalidade do domínio que o narrador supostamente tem da sua ficção no fingimento da inépcia, evidencia a inépcia real da relaçăo desigual. É sua materialidade que a faz comovente e dolorosa, portanto, quando se observa que a relaçăo entre a estupidez e a racionalidade passa justamente pela ficção, năo 
como tema tratado representativamente, mas como relação que evidencia o lugar precário da razão, definido não pelo que se diz nem pelas coisas sobre as quais se fala, mas sempre pelo lugar prático donde se enuncia. Aqui o narrador equilibra-se mal, e não podia ser diverso, pois é lúcido acerca da sua posição como emissário de um autor implícito que sabe que a estupidez é a ausência de obra, como escreve Shoshana Felman em seu La folie et la chose littéraire, dando-se como inacabamento contínuo de um sentido que não cessa de se transformar enquanto se dá ao desconhecimento de si mesmo. Macabea é a própria ausência de obra, sem projeto que é, simetricamente inversa ao narrador, cujo projeto é justamente a obra como ausência ou inacabamento. No final, quando começa a querer ter mais cabelo e se torna "uma pessoa grávida de futuro" (p.25), quando aprende que deve lavar a cabeça com sabão Aristolino, quando Madama Carlota lhe profetiza o bom partido do gringo, é de se notar que ela morre, ou melhor, é morta pelo narrador. "Este livro é um silêncio. Este livro é uma pergunta" (p.21). Mas por que morre? Porque a auto-dissolução do narrador é, ainda, a etapa necessária da razão insuficiente? Porque a obra só se completa efetivamente como imaginário dominante e este é prostituído? Porque então se deslisa da estupidez que não se sabe para a região da besteira institucional onde se voa mais baixo que os planos de ascensão de Olímpico, de Glória? Porque a morte $\epsilon$, nesta história horrível, "personagem predileta" (p.101)? A dissolução da personagem e do narrador não é total, contudo, pois ainda em sua morte o texto recusa a conciliação mítica.

Retome-se, pois, a questão aflorada atrás sobre o procedimento do narrador de fazê-la calar ou falar. Quando a põe falando, é imediatamente grotesca, pois paródica, a despeito de si mesma, dos critérios que regem o verossímil das trocas simbólicas. A coisa se evidencia na relação muda com Olímpico de Jesus que, seguindo a motivação das alturas implícita em seu nome, É um vencedor, o deputado, futuro: "você sabe se a gente pode comprar um buraco?" (p.69). Solta no palco, as falas lhe são postas na boca pelos cordéis habilmente visíveis do narrador e apontam ainda mais esta vez para o que socialmente é convenção do nonsense ou inexistência: qual é o valor de uso ou troca de um buraco? Aliás, observa o narrador insistentes vezes, Macabea é atenta para o que ninguém vê: portão enferrujado, capim ralo entre pedras, canto de galo, tique-taque da Rádio Relógio... Por isso, em sua sonsice é paradoxalmente filósofa, eis o sentido do nonsense dela, cuja luz negra ilumina com rigor as luzes do senso comum: "...o que quer dizer 'eletrónico'?" (p.61); "Eu gosto tanto de parafuso e prego, e o senhor?" (p.54); "O que quer dizer 'élgebra'?" (p.61). E, ainda, procedimento que cita Lewis Carroll ou qualquer fala sonsamente astuta de sofista grego: "Ele: - Pois é. Ela: Pois é o quê? Ele: Eu só disse pois é! Ela: Mas 'pois é’o quê?" (p.58), diálogo maluco em que sua 
(17): 107-122, 1989.

fala joga com a referência e o sentido no velho paradoxo da regressão infinita do pressuposto. $O$ que mais uma vez implica que sua plenitude estúpida não é uma carência, enfim, mas que seu pensamento se pensa como diferencial da relaçāo desigual. Os procedimentos que a fazem falar a dramatizam, desta forma, contrastivamente: é grotesca, porque deformação (O termo, infelizmente, determina-se clássica e negativamente, como um segundo em relação a um primeiro posto como bem formado, sua idealidade e regra; seria oportuno pensar que Lispector é mais hábil e moderna, produzindo deformação imanente, sem modelo, na personagem, quando dissolve as formas sensatas - que se lê, evidentemente, como da personagem, devido à regra encenada pela racionalidade do narrador). A deformaçāo também é crítica, em outro registro, se Macabea for lida no intertexto das representações piedosas do explorado, que geralmente fazem dele um oprimido ser de exceção na idealização que começa com a da própria miséria artística. $O$ texto de Lispector desidealiza na deformação, repropondo a coisa bruta da contradição, eis também o realismo da escritora intimista.

É talvez mais oportuno, por isso, pensar nos procedimentos que a fazem calar. Citam-se apenas dois, aqui, que decorrem mais uma vez da situação e posiçāo representadas do narrador. Um deles, plenamente institucionalizado, pelo qual Rodrigo S. M. trai sua situação, consiste em classificá-la como "neurótica", termo que ocorre tanto por parle do narrador quanto por conta de uma personagem, o médico de pobres. Ao fazê-lo, remetem Macabea a uma instância de anormalidade que justificaria sua mudez pela regra implícita, obliterando a relação desigual em que a "neurose" se enuncia assim, também é sintomático que o médico estúpido lhe aconselhe um psicanalista, estupidamente. $O$ outro procedimento - nele vários motivos se associam, talvez reconhecimento pleno de sua impotência e má-consciência como narrador, talvez reconhecimento da inviabilidade narrativa do "digo que digo" de sua inépcia e, certamente, realização plena do dispositivo é matá-la, ou melhor, matar Macabea, para que a alegoria Macabea sobreviva. O que implica também uma escolha entre possíveis narrativos que não são opções meramente narrativas: coerência admirável do autor implícito, reconhecimento de que outra solução seria falsa, aqui também Clarice Lispector toma posição.

O narrador reconhece o ato como traição e culpabilidade: "Alé tú, Brutus?!" (p.102). Culpa e traição, contudo, sāo efeitos ainda da representação do narrador como individualidade empírica, Rodrigo S. M., mais ou menos empático na relação com a personagem individualizada. É que, como a dos suicidas, que se matam porque querem viver, a morte de Macabea figura, pela recusa da vida que o texto representa em formas degradadas, a utopia de outra, ainda por vir: "Sim" (p.104). 
O dispositivo opera, portanto a um termo o contato do narrador com Macabea, limite da sua auto-representaçāo que dissolvendo-se enquanto o limite é dissolvido, figura o silêncio e o fim. Contudo, como diria um barroco muito caro, muito mais é perpetuar a vida de Macabea na morte que tirar a vida na morte de Macabea, porque tirar a vida dela é faze-la morrer num instante, perpetuá-la é fazé-la viver toda a vida. É que sua morte não é o happy end conciliado pelo Ministro da Educação e Cultura, obviamente, no prefácio "O Grito do Silêncio":

"O 'Mercedes amarelo' não pode vencê-la. Ao ser colhida por ele (e eu que pensava que não se podia escrever mais histórias com happy end) já havia assumido para sempre a felicidade impossível, num esforço sobre-humano que consistiu em mitificar o pesadelo em sonho. Mais do que um minuto de siléncio, ela merece a vida" (p.12).

Certamente que merece - mas não assim, regressiva, mitificando o pesadelo em sonho - porque o final é efetivamente insuficiente, monstruoso e triste, dando-se como a divisão mais violenta deste texto violentíssimo de Clarice Lispector. A solução do livro também é só uma rima, não rica como a do Ministro, paupérrima, determinada pelos materiais da intervenção literária da Autora. Ao contrário do que afirma o prefaciador, Lispector sabe que a vida não é um problema de linguagem e produz essa morte como fratura, marca da contradiçāo irredutivel que não admite mitificação também literária: "Não sou vendávell Ai de mim, todo na perdição e é como se a grande culpa fosse minha" (p.103). Apenas parcialmente, como parcialidade da divisão da razão, Macabea mantém-se alegoria virgem e intocada de morte no mistério da sua estupidez, ela que só começa a ter um futuro no contato com os limites institucionais de sua inutilidade, insignificância e estupidez. Aqui, a alegoria tem nome de posiçăo: negação e recusa, desejo decepcionadamente utópico do narrador e seu Autor. Apenas parcialmente, como parcialidade da razão da divisão, Macabea também morre, vencida estrondosamente pelo mundo no qual é dispensável: "Vencera o Príncipe das Trevas" (p.102) o Mercedez Benz amarelo é bem a figura de sua eficiência, de seu triunfalismo.

As duas parcialidades não formam um 'todo harmônico, evidentemente, pois não há todo. Pela última vez nesta não-obra-prima de Clarice Lispector,eis o dispositivo da despersonalização soberba que, ao afirmar a vida embutida no siléncio das gentes como Macabea, nega a mesma despersonalização, fazendo vibrar na inépcia atual a sua razão de dispositivo que também deve dissolver-se. Aliás, não esquecer que por enquanto é tempo de morangos. 